\title{
Clinical, Paraclinical and Etiological Aspects of Cirrhosis in a Department of Internal Medicine in Senegal
}

\author{
Daouda DIA*, Gnagna Diouf, Mamadou Ngoné Gueye, Cheikh Ahmadou Bamba Cisse, Moustapha Cisse and \\ Mouhamadou Mbengue
}

Cheikh Anta Diop University, Senegal

Submission: December 14, 2018; Published: February 04, 2019

"Corresponding author: Daouda DIA, Cheikh Anta Diop University, Hôpital Général de Grand Yoff, Dakar, Senegal Egypt

Keywords: Cirrhosis; Gastrointestinal bleeding; Bacterial peritonitis; Hepatocellular carcinoma; Pathology; Hepatomegaly; Limb edema; Jaundice; Stellate angiomas; Palmar erythema; Clubbing; Asterixis; Fetor hepatis; Thoracoabdominal collateral venous circulation; Ascites; Splenomegaly

\section{Introduction}

Because of its many and various complications, cirrhosis is the cause of more than a million deaths worldwide. The African continent is one of the most affected areas because of the high endemicity of chronic viral infections B and C which constitutes one of its main etiologies [1-3]. Scientific work on its complications is available in Senegal (in particular on gastrointestinal bleeding [4], spontaneous bacterial peritonitis [5] and hepatocellular carcinoma [2]), but over the last twenty years, we have not found any study on the description of cirrhotic patients as a whole. Thus, the objective of our study was to determine the socio-demographic, clinical, paraclinical and etiological features of cirrhosis in hospitalized patients in the Internal Medicine department of the General Hospital of Grand Yoff (Dakar) in order to contribute to an update of knowledge on this pathology in Senegal.

\section{Patients and Methods}

This was a descriptive and transversal study from January 2014 to December 2015 in the Internal Medicine department of General Hospital of Grand Yoff in Dakar, Senegal. All records of hospitalized patients diagnosed with cirrhosis were collected. The diagnosis of cirrhosis was retained either a bundle of arguments, or a liver histology. The bundle of arguments included clinical and paraclinical data. The clinical data were one or more of the following signs: hepatic atrophy or hepatomegaly, limb edema, jaundice, stellate angiomas, palmar erythema, clubbing, asterixis, fetor hepatis, thoracoabdominal collateral venous cir culation, ascites, splenomegaly. The paraclinical data were biology (reduction of prothrombin time, hypoalbuminemia, thrombocytopenia), medical imaging (ultrasound or CT scan showing at least one of the following signs: dysmorphic or irregularly contoured liver, heterogeneous or nodular hepatic parenchyma, dilatation of the portal vein, splenomegaly, ascites, portal circulation derivations) and digestive endoscopy revealing esophageal or gastric varices or portal hypertensive gastropathy. From the selected files, we collected the age and sex of the patients, the noted clinical and paraclinical abnormalities, the Child-Pugh stage and the determined etiology of cirrhosis.

\section{Results}

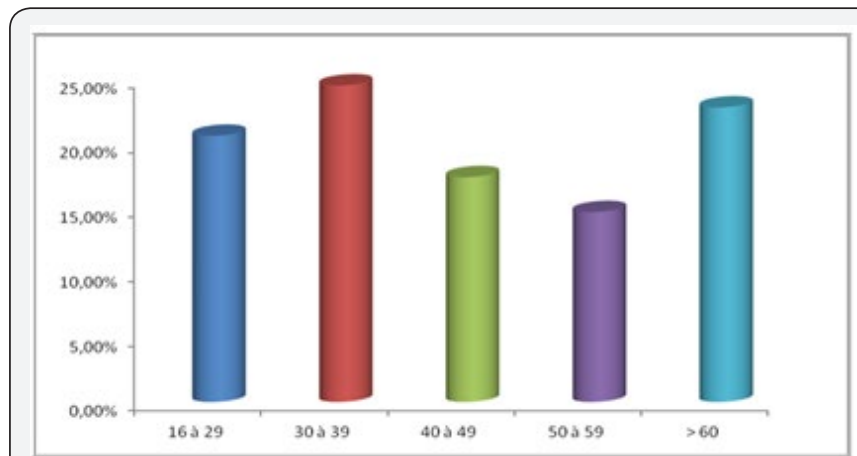

Figure 1: Distribution of patients by age.

The prevalence of cirrhosis was 9.1\% (102 patients). The mean age of the patients was 44.5 years (range, 17 to 85 years) 


\section{Advanced Research in Gastroenterology \& Hepatology}

and the sex ratio 2.8 (75 men). The distribution of patients by age is shown in Figure 1. The main reasons for hospitalization were ascites (44.1\%), abdominal pain (27.4\%), gastrointestinal bleeding (17.6\%) and jaundice (13.7\%). The dominant clinical and laboratory abnormalities are shown in Table 1. Upper digestive endoscopy performed in $73.5 \%$ of patients revealed signs of portal hypertension in $80 \%$ of cases. Medical imaging (ultrasound in $87.2 \%$ of patients and / or computed tomography in $41.2 \%$ of patients) was contributive in 93 patients $(91 \%$ of cases). Hepatic biopsy was performed in 7 patients $(6.8 \%$ of Comments

Table 1: Clinical and biological abnormalities in our patients. cases). The prognostic scores of Child-Pugh and MELD and the various complications of cirrhosis are shown in Table 2. The etiologies found were viral hepatitis B (55.9\%), alcohol (6.8\%), metabolic syndrome (4.9\%), autoimmune hepatitis (4.9\%), viral coinfection B and D (0.9\%), viral hepatitis C $(0.9 \%)$, and genetic deficiency MDR3 (0.9\%). The mean hospital stay of our patients was 10 days and mortality were $17.6 \%$. The causes of death were hepatocellular carcinoma ( 9 cases), gastrointestinal bleeding ( 3 cases), hepatorenal syndrome ( 2 cases), hepatic encephalopathy ( 2 cases) and spontaneous bacterial peritonitis ( 2 cases).

\begin{tabular}{|c|c|c|}
\hline \multicolumn{2}{|c|}{ Number of Cases } & Frequencies \\
\hline \multicolumn{2}{|c|}{ Clinical Abnormalities } \\
\hline Ascite & 70 & 68,8 \\
\hline Hepatomegaly & 67 & 55,7 \\
\hline Jaundice & 53 & 31,9 \\
\hline Splenomegaly & 34 & 19,6 \\
\hline Abdominal collateral circulation & 20 & 16,6 \\
\hline Limb edema & 17 & 78,4 \\
\hline Drop of PT & Biological Abnormalities & 77,5 \\
\hline Cytolysis & 80 & 77,5 \\
\hline Hyperbilirubinemia & 79 & 76,5 \\
\hline Anemia & 79 & 53,9 \\
\hline Hypoalbuminemia & 78 & 51,9 \\
\hline Cholestasis & 55 & 19,6 \\
\hline Thrombocytopenia & 53 & \\
\hline
\end{tabular}

Table 2: Prognostic scores and complications of cirrhosis.

\begin{tabular}{|c|c|c|}
\hline & Number of Cases & Frequencies \\
\hline \multicolumn{3}{|c|}{ Prognostic Scores } \\
\hline Child-Pugh A & 23 & 22,5 \\
\hline Child-Pugh B & 46 & 45,1 \\
\hline Child-Pugh C & 33 & 32,4 \\
\hline MELD $\leq 15$ & 16 & 15,7 \\
\hline MELD > 15 and $\leq 30$ & 53 & 52 \\
\hline MELD > 30 & 33 & 32,3 \\
\hline \multicolumn{3}{|c|}{ Complications } \\
\hline Ascite & 70 & 68,6 \\
\hline Jaundice & 53 & 51,9 \\
\hline Hepatocellular carcinoma & 33 & 32,3 \\
\hline Gastrointestinal bleeding & 26 & 15,5 \\
\hline Hepatic encephalopathy & 20 & 19,6 \\
\hline Hepatic encephalopathy & 14 & 20 \\
\hline Renal failure & 11 & 10,7 \\
\hline Other infections & 9 & 8,8 \\
\hline
\end{tabular}


The hospital prevalence of cirrhosis varies widely by country and by specialization. In Hepato-Gastroenterology departments, it is $17.6 \%$ in Uganda [6], $22.6 \%$ in Benin [7] and $15 \%$ in France [8]; in Internal Medicine department, it is $3.2 \%$ in Congo [9]. Our patients have an average age of 44.5 years and those aged 30 to 39 represent the majority (Figure 1 ). We had already reported in Senegal the same average age in 55 cirrhotic patients [5]. In other Sub-Saharan African countries, such as Mali, Burkina-Faso and Central Africa Republic, the ages of cirrhotic patients are similar [10-12]. The age of cirrhotic patients is young in southern countries in relation to the youth of the population, but also because of the endemicity and the early onset of chronic viral infections B and C. Men seem more exposed to the risk factors explaining the male predominance noted in the majority of studies [1-9,13,14]. As in the other African series [5-12], the clinical and biological manifestations as well as the prognostic stages reveal severe stages because of the delay of the diagnosis (Tables 1 \& 2). In Wang's patients in China [14], the mean MELD score was 15.3 while $84.3 \%$ of our patients had a score greater than 15 and $32.3 \%$ had a score above 30 . The mortality rate is also high in relation to the absence of liver transplantation in our low-resource countries and the difficult access to other means of treatment such as human albumin and therapeutic endoscopy [13]. Autoimmune, metabolic and genetic causes are becoming more individualized despite the high prevalence of viral hepatitis B in Senegal [15].

\section{Conclusion}

Cirrhosis often affects young adults in Senegal with a severe presentation. Prevention against the hepatitis B virus and recovery of the technical plateau would help its better management.

\section{References}

1. Groc S, Abbate JL, Le Gal F, Gerber A, Tuaillon E, et al. (2018) High prevalence and diversity of hepatitis $B$ and hepatitis delta virus in Gabon. J Viral Hepat 26(1): 170-182.

2. Ka MM, Ndiaye MF, Herve P, Legueno B, Diop BM, et al. (1996) Hepatitis $\mathrm{B}$ and $\mathrm{C}$ viruses in hepatocellular carcinoma in Senegal Dakar Med 1: $59-62$.

3. Njouom R, Tejiokem M, Texier G, Fontanet A (2015) Prevalence of hepatitis B, hepatitis C and hepatitis D virus infections in Cameroon: results from a national population-based survey (The ANRS 12289 project). J Viral Hepat 22(2): 1-2.

4. Mbengue M, Diouf ML, Pouye A, Ndiaye FS, Mbengue I, et al. (2003) Gastrointestinal hemorrhage in cirrhosis at Dakar. Predictive factors study. Dakar Med 48(3): 213-218.

5. Dia D, Serme YK, Bassene ML, Halim A, Diallo S (2014) Infection spontanée du liquide d'ascite à Dakar, Sénégal: étude de cinquantecinq patients cirrhotiques. Med Sante Trop 24: 55-57.

6. Apica BS, Ocama P, Seremba E, Opio KC, Kagimu MM (2013) Decompensated cirrhosis-related admissions in a large urban hospital in Uganda: prevalence, clinical and laboratory features and implications for planning patient management. Afr Health Sci 13(4): 927-932.

7. Sehonou J, Kodjoh N, Sake K, Mouala C (2010) Cirrhose hépatique à Cotonou (République du Bénin): aspects cliniques et facteurs liés au décès. Med Trop 70: 375-378.

8. Condat B, Remy AJ, Jouannaud V, Lahmek P, Rosa I, et al. (2015) Groupe d'étude de l'ANGH. Le recours aux soins pour cirrhose dans les services d'hépato-gastroentérologie des centres hospitaliers généraux français en 2012. Bull Epidemiol Hebd 24(25): 450-456.

9. Bossali F, Deby G, Atipo-Ibara BI, Koumou-Okandzé L, Kamba SK, et al. (2015) Survie à deux ans des cirrhotiques suivis à Pointe-Noire de 2005 à 2014.J Afr Hepatol Gastroentéro 9: 39-43.

10. Diarra M, Konaté A, Soukho A, Dicko M, Kallé A (2010) Aspects évolutifs de la maladie cirrhotique dans un service d'hépato-gastroentérologie au Mali. Mali Med 25: 42-46.

11. Nacoulma EWC, Zongo S, DraboYJ, Bougouma A (2017) Les différents types d'anémie au cours des cirrhoses au Centre hospitalier universitaire Yalgado Ouedraogo de Ouagadougou (Burkina Faso). Sante 17: 87-91.

12. Ouavene JO,Koffi B, MobimaT, Bekondji C,Massengue A (2013) Cirrhoses du foie à l'hôpital de l'amitié de Bangui aspects épidémiologiques, cliniques, échographiques et problèmes de diagnostic. JAIM 5-12.

13. Morsy KH, Ghaliony MA, Mohammed HS (2014) Outcomes and predictors of in-hospital mortality among cirrhotic patients with non-variceal upper gastrointestinal bleeding in upper Egypt. Turk J Gastroenterol 25(6): 707-713.

14. Wang X, Lin SX, Tao J, Wei XQ Liu YT, et al. (2014) Study of liver cirrhosis over ten consecutive years in Southern China. World J Gastroenterol 20(37): 13546-13555.

15. Dia D, Guèye MN, Diouf G, Diallo M, Boye A, et al. (2015) Cirrhose biliaire primitive: à propos de 2 cas à évolution sévère au Sénégal. J Afr Hepatol Gastroenterol 9(4): 163-165.

\section{Your next submission with JuniperPublishers will reach you the below assets}

- Quality Editorial service

- Swift Peer Review

- Reprints availability

- E-prints Service

- Manuscript Podcast for convenient understanding

- Global attainment for your research

- Manuscript accessibility in different formats

( Pdf, E-pub, Full Text, audio)

- Unceasing customer service

Track the below URL for one-step submission https://juniperpublishers.com/online-submission.php 